\title{
TECHNOLOGY PROVIDING SECONDARY PROTECTION METAL STRUCTURES AGAINST CORROSION UNDER AGGRESSIVE IMPACT OF METALLURGICAL PRODUCTION
}

\author{
Gibalenko O.M., Doctor of Technical Sciences, \\ Professor \\ grin196102@gmail.com, ORCID:0000-0003-2979-5225 \\ Bocharova O.A., PhD, Associate Professor, \\ E-mail: kaleriabocharova@gmail.com, ORCID:0000-0003-3993-5842 \\ Melnik G. O., Postgraduate \\ E-mail: melnikpstu@gmail.com, ORCID:0000-0002-1084-5539
}

\begin{abstract}
.
Research is aimed at the formation and development of innovative developments to increase the metal structures corrosion protection, as an important means of ensuring the quality and safety industrial facilities. The method determining the corrosion destruction signs, the procedure of monitoring and carrying out measures to diagnose the technical condition of lattice metal structures according to the level of corrosion hazard were adopted. The nomenclature indicators and control methods (conformity assessment) of determining parameters primary and secondary protection metal designs against corrosion is established. During this study, the lattice structures operational condition loader crane's girder structure was considered. It is revealed that operation of the crane is carried out in difficult production conditions operating environment's aggressive influence in combination with considerable dynamic loadings working operations loading technological process, unloading, sorting (averaging) of ore yard's charge of blast furnace shop. Based on the study structures corrosion condition and operating conditions, measures have been developed to increase the durability ore-grab crane of the reloader. Based on the analysis of the principles of the ISO 9001 process approach, the development and implementation design solutions to extend the structures service life in aggressive environments of metallurgical production. It is proved that the procedure of making constructive and technological decisions, performance works on increase corrosion resistance promotes maintenance conditions of resource saving and technological safety industrial constructions. The principles process is offered to develop and implement design measures to extend the service life of structures in aggressive environments metallurgical production are proposed. Constructive and technological measures to ensure durability in accordance with the requirements of the building structure corrosion risk have been developed, which are determined by the critical indicators metal structures protection in the conditions corrosion influences within their limit values.

Key words: metal structures, loader crane, aggressiveness of environment, operation, corrosion wear, resource.

Introduction. One most important principles of achieving the structures' reliability and durability is the implementation process approach's principles to the operation and maintenance [1]. International standards doctrine of ISO 9000 quality system certification means that the main achievement of these goals is a process approach in ensuring the quality of construction products at all stages of the building or structure's life cycle [2].

The work is based on the study of the lattice structure's operational condition loader crane's girder structure. The service life of the crane is more than 50 years, which exceeds the standard service life (about 20 years). Based on the results of field research, it was found that the reloader's operation is in a very difficult operational mode and the crane is close to the development its resource (based on the calculation of the number of operating cycles). According to the provisions of ISO4301-2: 2015, the load distribution for the crane $\left(K_{p}\right)$ depends on the indicators: the average number of cycles work with the level mass a particular load $\left(C_{i}\right)$; total number operating cycles with all loads $\left(C_{m}\right)$; the
\end{abstract}


value the masses of individual loads (load levels) in the typical use crane $\left(P_{i}\right)$; the mass of the largest load (nominal load) that can be lifted by crane $\left(P_{\max }\right)$.

$$
K_{p}=\sum\left[\frac{C_{i} P_{i}}{C_{T} P_{\max }}\right]^{3}
$$

Complex production processes tend to increase the aggressive impact of the operating environment. In combination with significant dynamic loads technological procedures of loading, sorting (averaging) ore yard's charge of blast furnace shop promotes decrease in metal designs' durability. Corrosion aggressiveness operating environment is due to the influence a number of such negative factors: industrial dust and metal structures' surface contamination; periodic humidification by precipitation; corrosion-aggressive allocations coke production, the formation of which occurs during coke's wet quenching. It is established that in order to prevent accidents, during the entire operation period, planned and metal structures' preventive repairs and crane's technological equipment were carried out, measures were taken to protect them against corrosion.

Analysis of recent research and publications. To control buildings' and structures' technical condition in their construction process, reconstruction, repair and operation provides a set targeted actions of technical diagnostics using including non-destructive testing methods based on the latest advances in science and technology [3]. Diagnostics questions a metalwork's technical condition of buildings and constructions demand the influence various operational and production factors for definition an actual condition and service life's forecasting [4].

The main task of research is to ensure the verification procedure, determining the state in which the object is currently. Thus, ways realization of check - software and hardware are considered. In the practice diagnosing the technical condition, both methods are used together, as the result effects of a given program cannot be replaced by the use of instrumentation or hardware.

Corrosion risk management of operated facilities includes control, regulatory, controlling and investment-technological components buildings and structures trouble-free operation in conditions $\mathrm{f}$ aggressive climatic and technological influences $[5,6]$. The use of rational measures metal structures' corrosion protection provides the opportunity to reduce, by about a quarter, the annual operating costs (associated with reliability and durability) only by improving the organization work on corrosion protection [7].

Selection of previously unsolved parts of the overall problem. From the standpoint of structural mechanics, the apparatus, the allowable reduction elements' bearing capacity for a given system structures' corrosion protection can be taken into account in the calculations of the boundary conditions using fictitious external loads [8]. The essence planned research is to substantiate the conditions of monitoring and diagnosis of corrosion's signs in the maintenance building metal structures on the actual condition [9].

European design standards (EN ISO12944, ISO8501 - ISO8504) define the regulatory requirements for the justification corrosion protection measures during the service life. This is due to the technical requirements that require the implementation corrosion protection's quality management based on approaches to the assessment boundary conditions in order to ensure the technological safety of buildings and structures. In accordance with the regulations, it becomes important to establish requirements procedure for detecting defects and damage. At the same time, there is a need to determine the most effective measures of primary and secondary protection against metal structures' corrosion, as well as the adoption of the necessary procedures to maintain the working condition of structures [10].

Setting objectives. The paper provides the improvement approach, which includes the main stages of technological safety's risk assessment: the appointment methods for controlling the structures' parameters on the damage indicators and the allowable maintainability interval value; indicators' quantitative assessment based on the calculation structures for corrosion resistance and durability; analysis of the vulnerability's level structures depending on the criticality degree (categories of defects and damage); assessment threats (categories of technical condition) in the 
operation conditions according to the actual condition at the established values of maintainability; implementation measures to restore performance, extend the life structures and reduce risk in the implementation of measures to ensure the reliability actual situation [11].

The description reliability indicators is performed using block diagrams, which are represented by flow graphs. The diagrams describe the changes in the corrosion state of metal structures, taking into account the design and technological options primary and secondary protection in the maintenance of facilities in the actual condition during the established service life. The structure of durability indicators of structures in corrosive environments includes calculation and experimental assessment, technical control and diagnostics of operational properties during the life cycle of steel structures (Fig. 1).

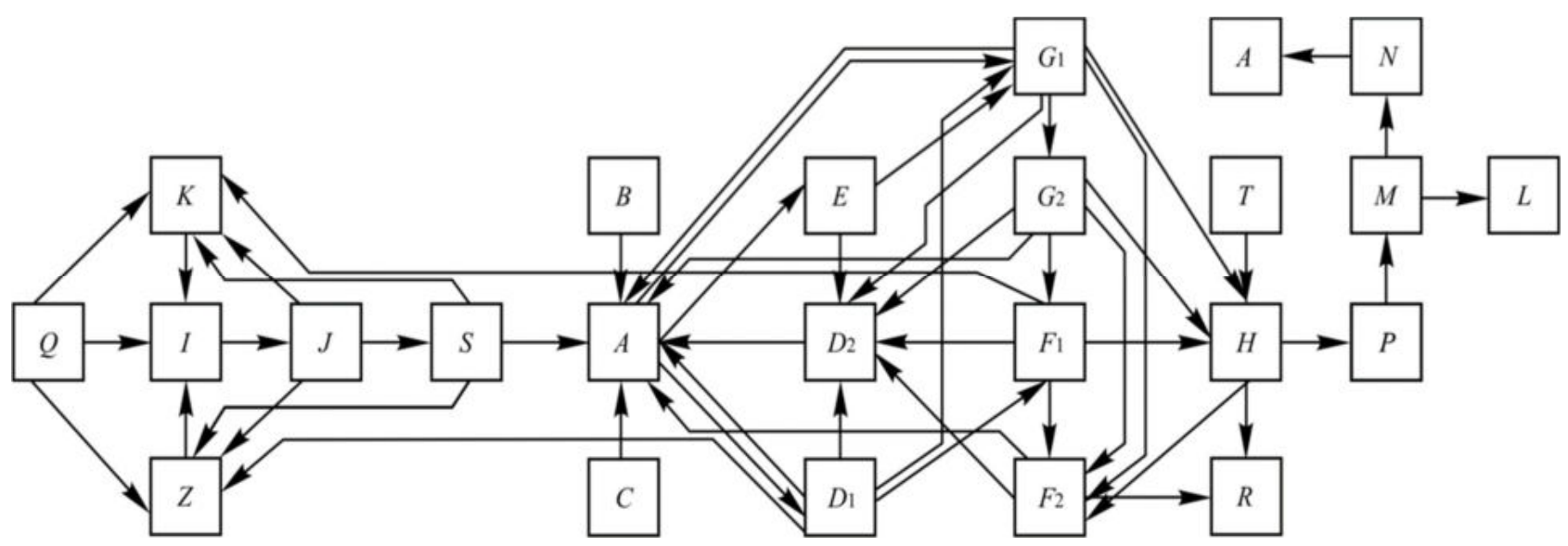

Fig. 1. Generalized structural model of design requirements for corrosion resistance, durability and maintainability in the operation metal structures.

Calculation of corrosion resistance is associated with the consideration primary and secondary protection measures based on the characteristics of the boundary conditions the first and second groups. Determination of corrosion resistance, maintainability and durability is performed according to the calculation schemes and data tables of the elements of the drawings of the KM. The calculated dependences for substantiation of constructive decisions of primary and secondary protection at the stage of KMD have the form:

I limit state:

$$
\begin{gathered}
\Phi / N+\left(1-\gamma_{z k}\right) \leq \Gamma / \gamma_{s r} \\
\left(1-\gamma_{z n}\right) \cdot A \cdot T_{H}^{c} \leq m \cdot \delta(1-1 / \Gamma) \\
\text { II limit state: } \\
F_{e}=\left(\frac{\Gamma}{\gamma_{z f}}-\frac{\left.\Gamma / \gamma_{z k}+1 / \Gamma\right)}{2}\right)^{2} \\
T_{z \gamma} \geq \gamma_{z n} \cdot T_{z}
\end{gathered}
$$

The analysis of influence constructive and technological features on quality indicators at production of works on anticorrosive protection is carried out [12].

Basic material and results. This approach was used in the diagnosis of technical condition and extension of the ore reloader's life by ensuring the durability and serviceability the girder metal structure (Fig. 1, Fig. 2). 


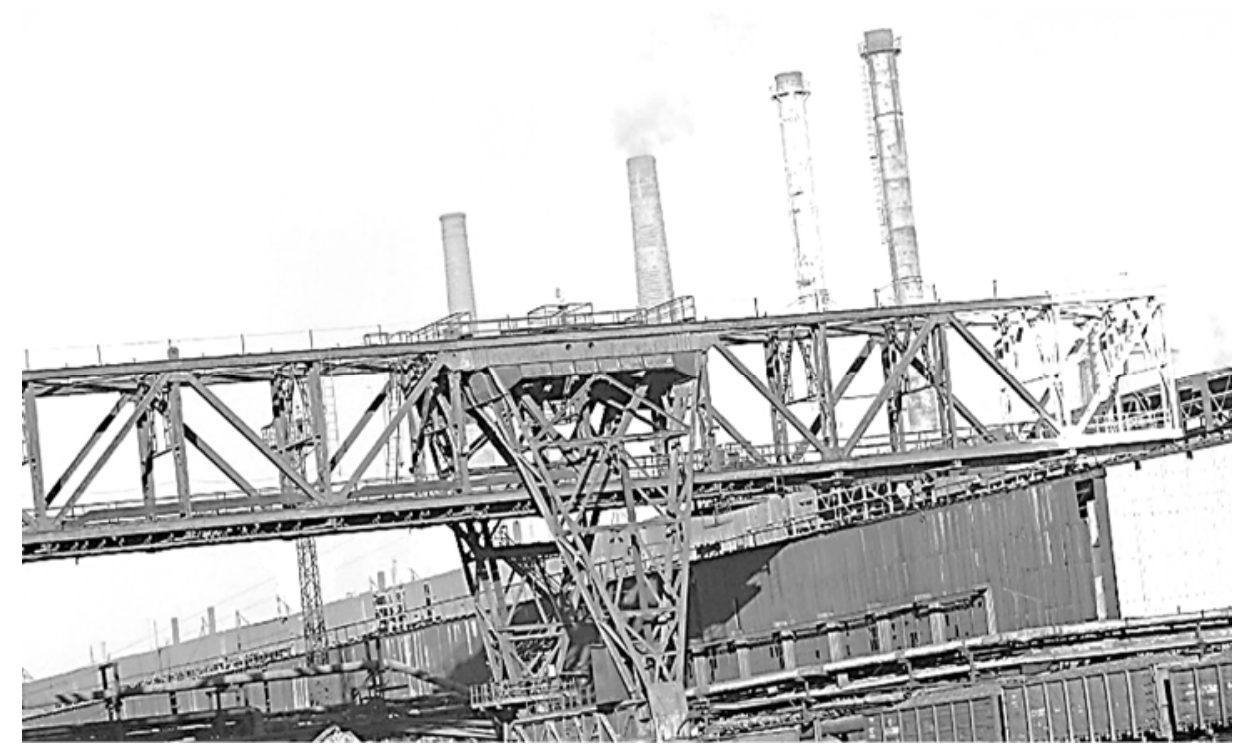

Fig. 1. Appearance load-bearing structure of the reloader (cantilever section).

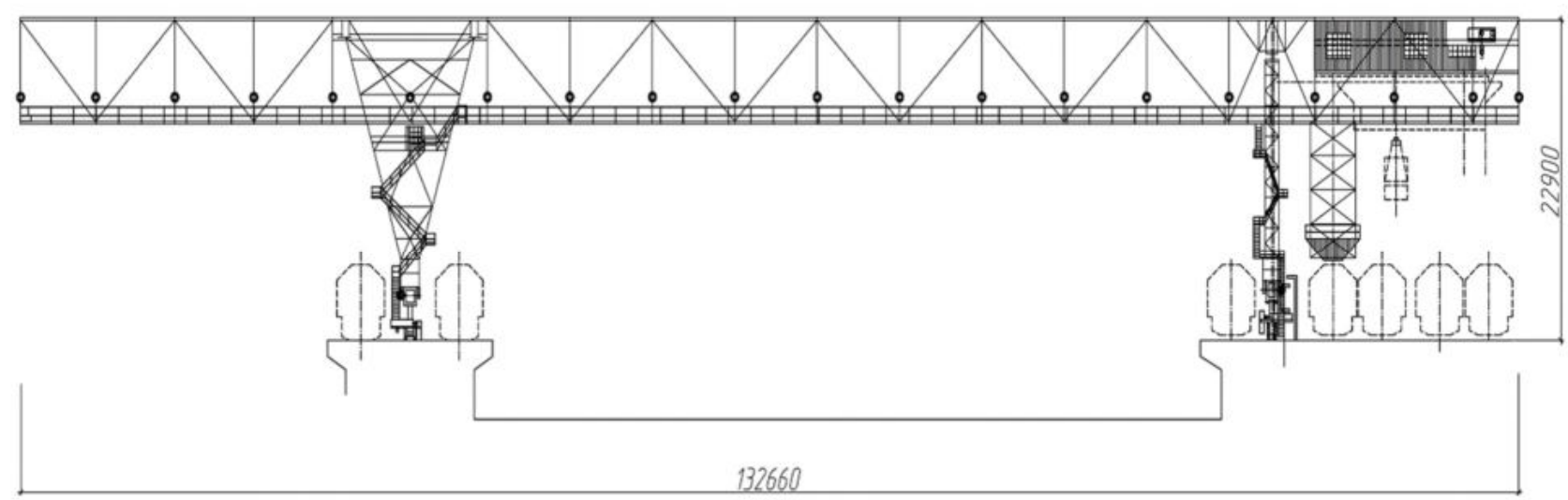

Fig. 2. Constructive scheme of the ore-grab crane.

The assessment metal structures' actual technical condition indicates the need to develop a methodological approach, which involves a comprehensive consideration of the parameters of the structures' actual condition and operation factors [13]. A systematic description diagnostic process according to the criterion of providing measures of primary and secondary corrosion protection allows the implementation of the reconstruction program on the basis of technical monitoring.

At the stage of assessing the technical condition, the values wear that exceed the maximum allowable (Fig. 3). Areas of operation structures that correspond to characteristic defects and damage have been identified (Fig. 4). 


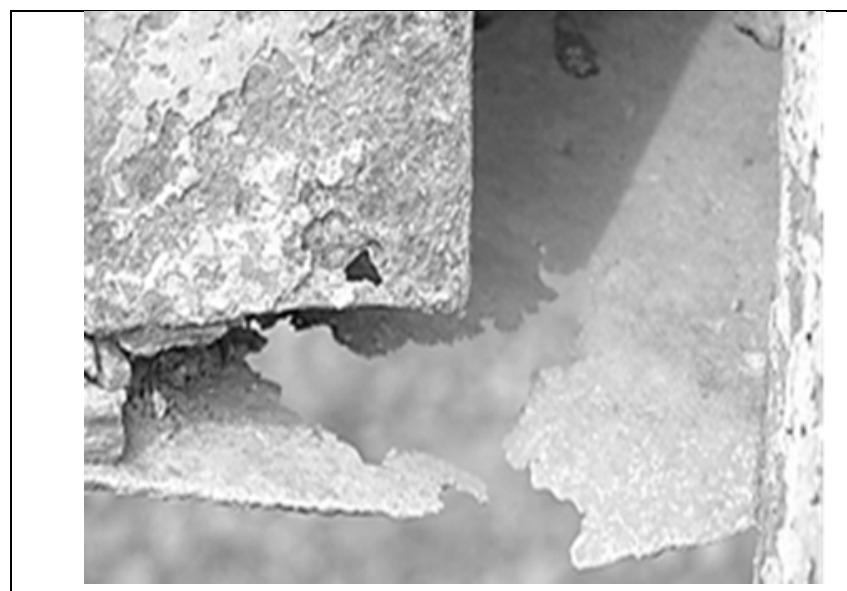

a)

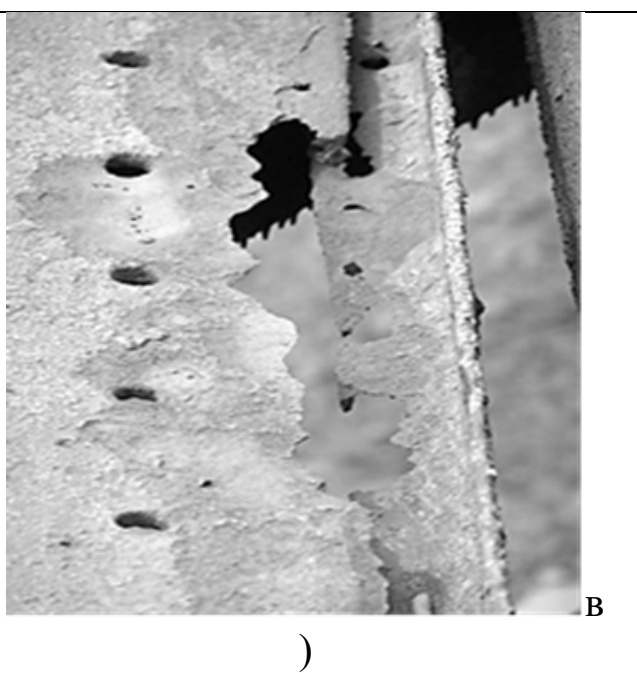

Fig.3 Typical defects and damage to structural elements of the girder structure: a) sheet structures and their connections; b) elements service structures, joints lattice structures.

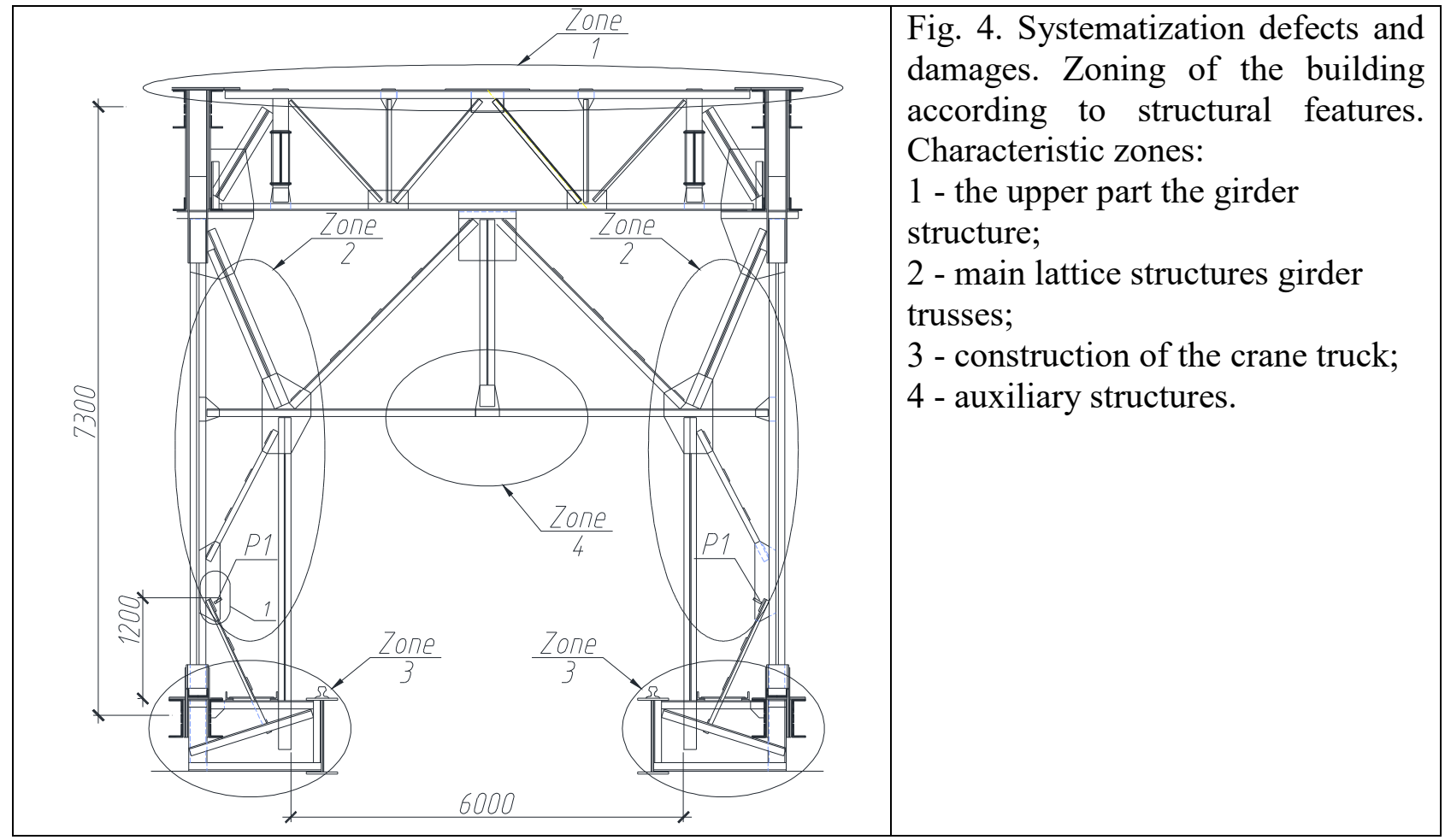

Reducing the serviceability creates the possibility achieving the structures' ultimate state due to the loss of nodes' bearing capacity at existing (passport) operating loads. On the basis of the performed experimental model researches riveted joints' restoration measures on heads' repair rivets with use washers and electric welding are developed.

In order to optimize the operating costs for repair and restoration work to maintain the working condition of the crane-reloader developed a research method and monitoring the technical condition reloader's metal structures. The technical task and performance restoration works which provide effective primary and secondary protection a metalwork against corrosion at maintenance of normal operation mode of the reloader's ore-grab crane are developed.

Basic material and results. Based on the results performed research, design and technological measures to ensure the effectiveness of primary and secondary corrosion protection are proposed. The program, which is developed before the start work, stipulates a list of organizational techniques aimed at identifying performers, coordinating their interaction. The list performance works, structure and technical documentation's terms and materials are defined. The task for the material supply, 
equipment and devices is issued in agreement with the nomenclature, stipulates the list and composition of the material used. At the preparatory stage, the qualifications contractors are identified. Regulatory support is approved and an independent examination is conducted in accordance with ISO9001 and ISO9002. When developing technical requirements for materials, protective coatings and technologies for their application, the indicators established by the international standard ISO12944 are used.

The technology providing access to structural elements and determining their actual technical condition (carrying out works on measuring geometric characteristics, determining the planned height of the main structures, assessing the state of corrosion protection) is developed and justified in accordance with the methods preparatory work. The works include: hydro-jet cleaning structures from dust, layers of rust and old paint; mechanical cleaning structures from corrosion products; surface treatment with compressed air. The works are performed in accordance with the map-scheme cleaning surfaces location with the indication of the approximate execution volumes.

The choice characteristics of a protective covering, preparation a surface is carried out depending on and according to instructions of ISO12944-5 (ISO12944-4) where requirements to drawing protective covering's material are stipulated. The offered durability a covering not less than 2 years.

Conditions corrosion effects are defined as highly aggressive (indicator of corrosion losses of unprotected steel up to $6900 \mathrm{~g} / \mathrm{m}^{2}$ *year). The operating mode corresponds to the corrosion category up to C5-1 (according to ISO12944-2) and contains the characteristic components of aggressive emissions: carbon oxides, coal dust, sulfur dioxide, hydrogen sulfide, ammonia, phenol, water vapor; $\mathrm{t}_{\max }=60{ }^{\circ} \mathrm{C}, \mathrm{W}=95 \ldots 98 \%$. Operating conditions according to GOST9.104 are marked $\mathrm{Y} 1$. Determination the color gamut paints and varnishes performed on the basis of the approved color scheme.

These requirements are set out in the technical documentation: drawings the stage A3; postoperative technological maps by types of work. Technical conditions are provided by the contractor before the start of work. Delivery of materials is carried out in the presence of certificates conformity with the necessary technical data reflecting requirements technical conditions or standards. At development technological maps of painting works' production, the methods recommended by the enterprise - the manufacturer of paint and varnish production are used.

Inspection structures' condition after work is performed for ultrasonic control of the elements' residual thickness. Based on the full-scale inspection data cleaned surfaces, measures are assigned to determine the riveted joints' condition nodal joints to assess the corrosion wear's degree (loss cross section) of the rivets' base metal (body), slit corrosion parameters in the joint. When performing a set of measures, the metal structures' technical condition was investigated: the main trusses of the crane bridge; wind farm; transverse trusses; driving beams and elements their fastening to farms; horizontal elm farms.

Conclusions. Based on the analysis field research data, the need to develop and adjust design solutions during monitoring to ensure the necessary passport characteristics and operation modes of the crane-reloader. It is possible to leave the truck on the cantilever section girder structure from the rigid support's side. On the basis of the data from field inspection cleaned surfaces measures for definition of riveted connections' condition nodal connections by selection of bearing designs' control samples and riveted connections are appointed. As result control samples' selection and research condition of knot connection's fragment the conclusion of metalworks' condition a console site of the crane's bridge from the rigid support is made. Paints' quality control and varnishes is performed by sampling and evaluation indicators set in the certificates for each batch. Their further processing is performed in accordance with ISO1512 and ISO1513.

Before the beginning surface anticorrosive works preparation according to working drawings instructions stage A3 is carried out. The application material protective layer is carried out according to the manufacturer's recommendations and technological characteristics set in the working drawings. At each stage works operational control with use of the corresponding control and measuring devices is provided: non-destructive control (definition of thickness of a covering according to ISO2808); 
destructive testing (determination of adhesion according to ISO2409 and ISO4624). To ensure coating quality control during the painting works, areas reference surface with a size of $1 \mathrm{~m}^{2}$ to $5 \mathrm{~m}^{2}$ with a homogeneous surface condition and aggressiveness of the operating environment are determined. Surfaces are used to determine the minimum acceptable standards for corrosion protection and quality control coating. Reference surfaces are documented and fixed on the structure itself. Author's supervision over the works performance is carried out by a specialized organization for operative quality control purpose anti-corrosion coatings, work coordination, observance of the requirements established in the design documentation.

\section{References}

[1] Paton B.E. (2015). Resource and safety issues for the operation of structures, structures and machines / Target comprehensive program of NAS of Ukraine. Coll. Sciences. Art. according to the results obtained in 2013 - 2015. NAN Ukraine. 816.

[2] ISO 9001:2015. Quality management systems - Requirements. Available at: https://www.iso.org/standard/62085.html.

[3] Shimanovskyj O.V. (2008). Conceptual bases of system of technical regulation of reliability and safety of building structures. Industrial construction and engineering. №1, 4-9.

[4] Cai, Y., Zhao, Y., Ma, X., Zhou, K., Chen, Y. (2018). Influence of environmental factors on atmospheric corrosion in dynamic environment. Corrosion Science, 137, 163-175. doi: https://doi.org/10.1016/j.corsci.2018.03.042.

[5] Gibalenko, A. N. Design requirements to structural steel durability based on level of in-dustrial facility corrosion hazard / A. N. Gibalenko, V. Korolov, J. Filatov // Aktualnie problemy konstrukcji metalowych: Abstr. II Polish-Ukrainian International Conference APMK (27.1128.11.2014). - Gdansk: University of Technology. - 2014. - P. 98-102.

[6] Corrosion of metals and alloys. Corrosivity of atmospheres - Classification, determination and estimation. 15. ISO 9223:2012.

[7] Ministry of Regional Development of Ukraine. (2014). Corrosion protection of metal structures. Design requirements. 74. B.2.6-193:2013.

[8] Korolev V.P., Filatov U.V., Selutin U.V. (2014). Development of corporate management system: technological safety of production facilities. Coll. Sciences. works of Ukrinstalkon them. V.M. Shimanovsky. Publishing house Stal. 14. $136-149$.

[9] Estimation of steel structure corrosion risk level / V. P. Korolov, Y. Vysotsky, O. M. Gibalenko, P. V. Korolov // Eurocorr-2010. The European Corrosion Congress (13.09-17.09.2010) / From the Earth`s Depths to Space Heights. - Moscow, 2010. - Book of Abstracts. - 534 p.

[10] Gibalenko A. Design requirements to structural steel durability based on level of industrial facility corrosion hazard / A Gibalenko, V Korolov, J Filatov // AKTUALNE PROBLEMY KONSTRUKCJI METALOWYCH. 2014, Gdańsk Poland. - P. 98-102.

[11] Korolov V. Design criteria of reliability and safety in the design of corrosion protection of structural steel / V. Korolov, Y. Vysotskyy, Y. Filatov / EUROCORR-2014. The European Corrosion Congress «Improving materials durability: from cultural heritage to industrial applications». - Pisa, Book of Abstracts. - 2014. - 88 p.

[12] Cai, Y., Zhao, Y., Ma, X., Zhou, K., Chen, Y. (2018). Influence of environmental factors on atmospheric corrosion in dynamic environment. Corrosion Science, 137, 163-175. doi: https://doi.org/10.1016/j.corsci.2018.03.042.

[13] Shimanovskyj O.V.., Gibalenko O.M., Onyshchenko A.M. (2020). An integrated approach to managing the corrosion protection of metal structures while ensuring technological safety in the condition's metallurgical enterprises. Coll. Sciences. works of Ukrinstalkon them. V.M. Shimanovsky. Publishing house Stal. 25-26. 39 - 58. 


\title{
ТЕХНОЛОГИЧЕСКОЕ ОБЕСПЕЧЕНИЕ ВТОРИЧНОЙ ЗАЩИТЫ МЕТАЛЛИЧЕСКИХ КОНСТРУКЦИЙ ОТ КОРРОЗИИ В УСЛОВИЯХ АГРЕССИВНЫХ ВОЗДЕЙСТВИИ МЕТАЛЛУРГИЧЕСКОГО ПРОИЗВОДСТВА
}

\author{
Гибаленко А.Н., д.Т.Н., профессор \\ grin196102@gmail.com, ORCID:0000-0003-2979-5225 \\ Бочарова Е.А., старший преподаватель, \\ kaleriabocharova@gmail.com ORCID: 0000-0003-3993-5842 \\ Мельник Г.А., аспирант, \\ Melnikpstu@gmail.com, ORCID: 0000-0002-1084-5539
}

Аннотация.

Исследования направлены на формирование и развитие инновационных разработок по направлению повышения коррозионной защищённости металлических конструкций, как важного средства обеспечения качества и безопасности эксплуатации промышленных сооружений. Усовершенствована методика определения признаков коррозионного разрушения, диагностики технического состояния решетчатых металлических конструкций по уровню коррозионной опасности. На основании изучения коррозионного состояния конструкций и условий эксплуатации разработаны мероприятия по повышению долговечности рудно-грейферного крана перегружателя. Установлены принципы конструктивных и технологических мер обеспечения долговечности в соответствии требованиям коррозионной опасности сооружения. Определены критические показатели защиты металлоконструкций в условиях коррозионных воздействий в пределах их предельных значений.

Ключевые слова: металлические конструкции, кран-перегружатель, агрессивность среды, эксплуатация, коррозионный износ, ресурс.

\section{ТЕХНОЛОГІЧНЕ ЗАБЕЗПЕЧЕННЯ ВТОРИННОГО ЗАХИСТУ МЕТАЛЕВИХ КОНСТРУКЦІЙ ВІД КОРОЗІЇ В УМОВАХ АГРЕСИВНИХ ВПЛИВІВ МЕТАЛУРГІЙНОГО ВИРОБНИЦТВА}

Гібаленко О.М., д.т.н., пр0000-0003-3993-5842 grin196102@gmail.com, ORCID:0000-0003-2979-5225

Бочарова О.А., старший викладач kaleriabocharova@gmail.com ORCID: 0000-0003-3993-5842

Мельник Г.О., аспірант melnikpstu@gmail.com, ORCID: 0000-0002-1084-5539 ДВНЗ «Приазовський державний технічний університет»

Анотація. Дослідження спрямовані на формування і розвиток інноваційних розробок у напрямку підвищення корозійної захищеності металевих конструкцій, як важливого засобу забезпечення якості та безпеки експлуатації промислових споруд. Удосконалено методику визначення ознак корозійного руйнування, діагностики технічного стану гратчастих металевих конструкцій за рівнем корозійної небезпеки. На підставі вивчення корозійного стану конструкцій і умов експлуатації розроблені заходи щодо підвищення довговічності рудно-грейферного крана перевантажувача. Встановлено принципи конструктивних i технологічних заходів забезпечення довговічності відповідно до вимог корозійної небезпеки споруди. Визначено критичні показники захисту металоконструкцій в умовах корозійних впливів в межах їх граничних значень.

Ключові слова: металеві конструкції, кран-перевантажувач, агресивність середовища, експлуатація, корозійний знос, ресурс. 